\title{
The effect of slope level and hydroseeding formula on the growth of Cyperus brevifolius and Pueraria javanica seedlings
}

\author{
ANISA ZAIRINA", YANI QUARTA MONDIANA \\ Forestry Program, Faculty of Forestry, Institut Pertanian Malang, Jl. Sukarno Hatta No 210, Malang 65141, East Java, Indonesia. \\ Tel.: +62-341-495541, Fax. +62-341-485539, `email: anisa.zairina85@gmail.com \\ Manuscript received: 25 August 2020. Revision accepted: 5 October 2020.
}

\begin{abstract}
Zairina A, Mondiana YQ. 2020. The effect of slope level and hydroseeding formula on the growth of Cyperus brevifolius and Pueraria javanica seedlings. Biodiversitas 21: 5008-5012. The aim of this study was to analyze the effect of the slope level on the growth of green kyllinga (Cyperus brevifolius) and puero (Pueraria javanica) seedling in a hydroseeding formula. The hydroseeding mixture consists of plant seeds, compost, soil conditioner, manure, and water. In addition, to all hydroseeding compositions, guar gum and a local microorganism mix were mixed until colloidal mulch was obtained. This study applied factorial design with slope level dan hydroseeding treatment as independent variables, while seed height, number of shoots, and number of leaves were the dependent variables. Data were replicated four times. The hydroseeding formula had a significant effect on all variables, except for the height of $C$. brevifolius seedlings. There was a significant interaction effect between the slope level and hydroseeding treatment on the germination rate of both species but the effect of this interaction was not significant on plant height and leaf number. The best germination rates were found in boxes with a slope of $100 \%$. This situation was consistent for both species. This indicated that both species had the potential to be used as pioneer plants in post-landslide reclamation with a slope of $100 \%$.
\end{abstract}

Keywords: Hydroseeding, landslide, native species, reclamation

\section{INTRODUCTION}

Indonesia is one of the most disaster-prone countries in the world and is frequently exposed to a range of hazards. One of the disastrous events is the occurrence of landslides. Most of the hilly and mountainous areas in Java have vulnerable soil characteristics (Hadmoko et al. 2010). The increasing agricultural cultivation and settlement rate leads to a parallel increase in areas of degraded soil conditions and steep slopes that need revegetation (Stanchi et al. 2012).

Management of landslides is generally carried out technically by building retaining embankments. This handler is more feasible on land with steep slopes. Meanwhile, steep slope below $110 \%$ still allows for the revegetation process. Research on types of landslide resistant plants generally focuses on woody plants such as longan, durian, Leucaena, and Queen Crape Myrtle. Vegetation of trees may help to prevent soil slippage and improve hillside stability through strengthening its roots (Stokes 2009). The plant species are suitable for latter succession, whereas, in an earlier situation, the best plants are the pioneer ones.

Hydroseeding with commercial seeds of fast-growing grasses and legumes is a common practice in revegetation. However, research on hydroseeding in Indonesia is few. Several previous studies have always associated with exmining land (Thomas et al. 2015; Yulianingsih and Arisoesilaningsih 2015). Meanwhile, hydroseeding is one of the revegetation actions that make it possible to overcome difficulties of manual planting. The hydroseeding formula can be applied in a relatively wide and steep area (Albaladejo et al. 2000). The presence of an adhesive in the formula increases the ability of the seeds to resist erosion.

A better knowledge of species characteristics and species-specific responses to hydroseeding components may help to improve the success and the cost-effectiveness of this restoration procedure (Clemente et al. 2016). The selection of the right plant species is essential to ensure the success and sustainability of revegetation. (Oliveira et al. 2013). On embankments, the use of non-native herbs to protect from erosion should be avoided because it may potentially dominate the community (García-Palacios et al. 2010). Therefore, native plant species are highly recommended because of their presumed ability to adapt to local abiotic and biotic conditions. The stability of the slope as a target should be in harmony with the surrounding environment. This goal may be successful with revegetation, as plant root systems fix soil against slippage (Stokes et al. 2009).

The ground cover plant in this study serves as a hindrance to soil erosion due to rainwater. For example, the selection of grass species is based on the fact that this type can cover the soil quickly and through the roots. Grasses and legumes are the types commonly planted in the early stages of land revegetation because they are pioneer species (Chen et al. 2014). The utilization of seeds for revegetation of land after landslides is based on the consideration that these plants have pioneer characteristics and are in high abundance. Ecologically, this plant has an important role because of its ability to grow and colonize a wide area 
(Jaffre 1992). The use of seeds is one of the types recommended for the hydroseeding process. To apply hydroseeding to landslide remnants, a precise formula is required that can be used on sloping lands. Generally, the formula consists of seeds, mulch, soil stabilizer, fertilizer, and water mixed in a container with a certain composition (Ministry of General Work and People Houses, 2018). The objective of this study was to analyze the effect of the slope level on the growth of green kyllinga (Cyperus brevifolius) and puero (Pueraria javanica) seedling in a hydroseeding formula.

\section{MATERIALS AND METHODS}

This research was conducted in May-September 2020 in a greenhouse and the Central Laboratory, Malang Agricultural Institute. The hydroseeding mixture consists of plant seeds, compost, soil conditioner, manure, and water. The seeds used are composed of 0.5 grams of $C$. brevifolius seeds and 3 grams of $P$. javanica seeds. The seeds were soaked for 24 hours and selected before the mixture. In addition, to all hydroseeding compositions, Guar Gum and a local microorganism mix were mixed until 7 liters of colloidal mulch was obtained so that it could be easily applied above the soil surface.

The media consisted of soil originating from landslides in Ngantang, Malang Regency, East Java. The soil was placed in $38 \mathrm{~cm} \times 28 \mathrm{~cm} \times 13 \mathrm{~cm}$ plastic boxes. The observation basins were placed on an iron frame that has three levels of the slope, $60 \%, 100 \%$, and $140 \%$. The selection of this level of slope adopts existing standards (Ministry of General Work and People Houses, 2018). The control media were composed of soil and seeds without a formula. The treatment had four replicates. Seed germination observations were carried out every week until the $40^{\text {th }}$ day. Treatments were conducted in a greenhouse.

The seed germination rate was determined by the percentage of seed viability/total seed applied. Seedling height was measured using a caliper, and the number of leaves was determined manually. Data on seed height, number of shoots, and number of leaves were tabulated and compiled using Microsoft Excel. The average treatment was analyzed using the Tukey HSD test at $\alpha=5 \%$ with SPSS 18.0 for Windows.

\section{RESULTS AND DISCUSSION}

\section{Results}

The slope level affects the seed germination rate of $C$. brevifolius $(\mathrm{F}=4.02, p<0.05)$. Treatment of hydroseeding formula has a significant effect on all variables, except $C$. brevifolius seedling height. There was a significant interaction effect of slope level and hydroseeding treatment of both species' germination rate $(\mathrm{F}=13.45, p<0.001$ for C. brevifolius; $\mathrm{F}=5.72, p<0.05$ for $P$. javanica ), but the interaction effect was not significant on the plant height and the number of leaves (Table 1).

Observations made on the $40^{\text {th }}$ day showed that the $C$. brevifolius germination rate was highest at the slope of $100 \%$ and the lowest at $140 \%$. The sprout was absent in control, with a slope of $140 \%$ (Figure 1.A). The highest grass seedling height was found at the slope of $140 \%$, whereas the lowest was found at a slope of $60 \%$ (Figure 1.B). A similar situation was observed on the number of leaves. There were highest on the slope of $140 \%$, while the lowest was found at the slope of $60 \%$ (Figure 1.C).

The $P$. javanica germination rate in treatment boxes was highest at the slope of $100 \%$ and the lowest at $140 \%$. The $P$. javanica sprout in the control boxes showed a contrast situation. Those were highest at the slope of $140 \%$ and lowest at $100 \%$ (Figure 2.A). The height of $P$. javanica seedling in treatment boxes was highest at the slope of $140 \%$ and lowest at $100 \%$. The $P$. javanica seedling's height in control boxes indicated a different situation; it was lowest at the slope of $140 \%$ and highest at the slope of $80 \%$ (Figure 2.B). The number of $P$. javanica leaves was highest at the slope of $100 \%$ in both treatment and control boxes (Figure 2.C).
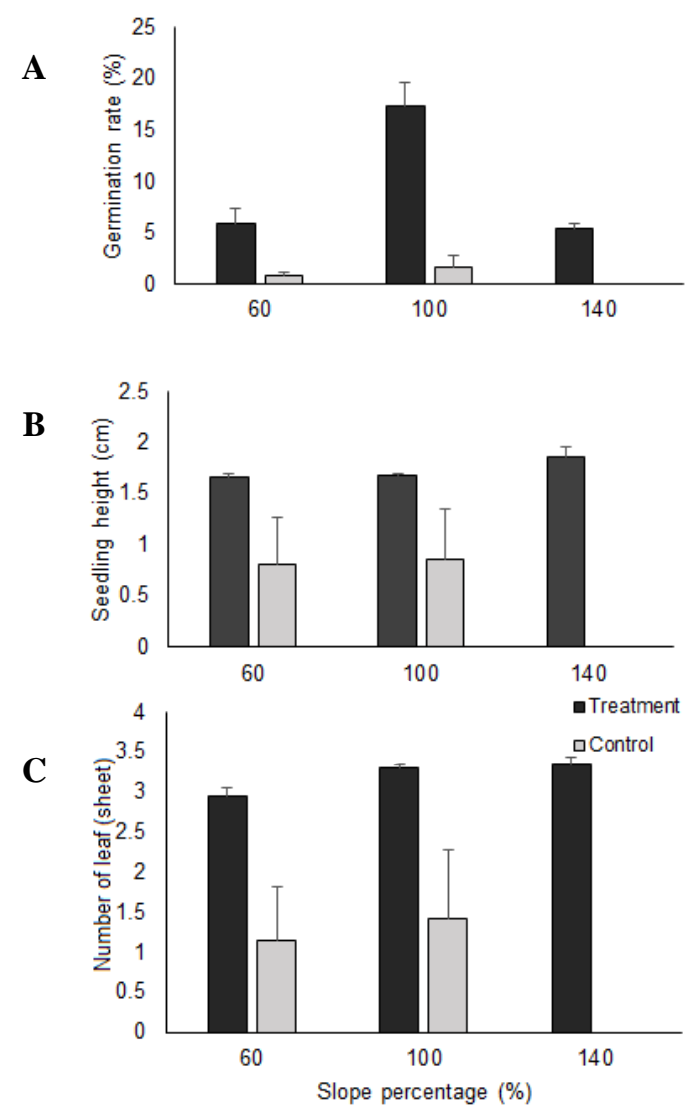

Figure 1. the Cyperus brevifolius germination rate, seedling height, and number of leaves planted on three slope levels of boxes by application of hydroseeding 
A
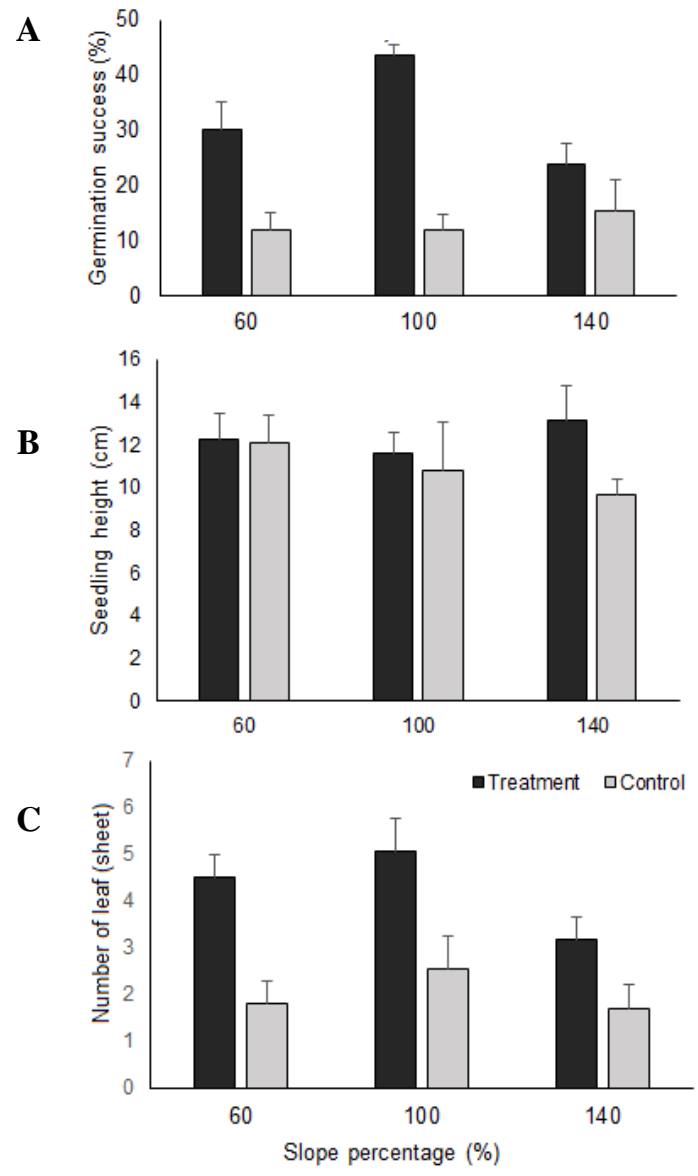

Figure 2. The Pueraria javanica germination rate, seedling height and number of leaves planted at three slope levels of boxes through the application of hydroseeding

Table 1. Summary of the F values followed by the probability of the effect of slope level and hydroseeding formula

\begin{tabular}{llll}
\hline Parameter & $\begin{array}{l}\text { Slope } \\
\text { level }(\mathbf{S})\end{array}$ & $\begin{array}{l}\text { Treatment } \\
(\mathbf{T})\end{array}$ & $\begin{array}{l}\text { Interaction } \\
(\mathbf{S} * \mathbf{T})\end{array}$ \\
\hline $\begin{array}{llll}\text { C. brevifolius } \\
\text { Germination rate }\end{array}$ & $4.02^{*}$ & $87.41^{* * *}$ & $13.45^{* * *}$ \\
$\quad$ Seedling height & $1.79^{\mathrm{ns}}$ & 0.59 & 1.15 \\
$\quad$ Number of leaves & $2.84^{\mathrm{ns}}$ & $45.22^{* * *}$ & 2.04 \\
$\begin{array}{llll}\text { P. javanica } \\
\text { Germination rate }\end{array}$ & $1.83^{\mathrm{ns}}$ & $51.80^{* * *}$ & $5.72^{*}$ \\
$\quad$ Seedling height & $2.91^{\mathrm{ns}}$ & $27.06^{* * *}$ & 2.21 \\
$\quad$ Number of leaves & $2.62^{\mathrm{ns}}$ & $41.35^{* * *}$ & 1.89 \\
\hline
\end{tabular}

Note: $* p<0.05, * * p<0.01, \mathrm{~ns}=$ not significant

\section{Discussion}

This study showed that the application of hydroseeding at a slope of $140 \%$ can still be used, but it results in a relatively low growth rate. The best germination rate was found in boxes with a $100 \%$ slope. This situation was consistent for both species. This showed that both species have the potential to be used as pioneer plants for post landslide reclamation with a slope of $100 \%$. Unlike $P$. javanica, green kylingga did not germinate in a control box with a $140 \%$ slope. This situation meant that the effect of the hydroseeding formula on the grass growth was substantial. The germination rate of Kylingga tended to be lower (less than 20\%) compared to that of $P$. javanica. This indicates that to achieve the optimum covering level $(100 \%)$, at least five times the seed in formula is required. Other studies have shown that the germination rate of Green Kylingga was relatively low (less than 5\%) (Anshari et al. 2018a).

The reclamation process using this cover plant is expected to be able to cover the steep slope surface after a landslide in the fastest possible way so as to reduce erosion by rainfall runoff. The effectiveness of cover plant in controlling erosion is influenced by cover characteristics. C. brevifolius is a species that has a high regeneration ability after disturbance. Other species that have similar abilities are Gnaphalium pensylvanicum, Oxalis corniculata, and Solanum nigrum (Weerasinghe et al. 2008). In studies carried out at $15 \%$ and $25 \%$ slopes, $C$. brevifolius, E. indica, and $C$. dactylon were the most common grass species. Even $C$. brevifolius has better chemical resistance than other types. The $C$. brevifolius has great potential for establishing soil seed banks because the viability of the seeds is longer than that of the other species studied. The $C$. brevifolius was observed to be the most persistent monocot weed among the $15 \%$ monocot weeds. Research conducted in the field showed that hydroseeding mulch could be used as a medium for germination and growth of pioneer local plant seeds, especially for Leguminosae plants. The germination percentage of Leguminosae seeds was higher than that of Cyperaceae and Poaceae seeds (Anshari et al. 2012a). Meanwhile, the growth of each specific family depends on its respective habitus. Although the root-shoot ratio of Cyperaceae was higher than that of the other two families, Leguminosae roots were longer (Anshari et al. 2018b).

Pueraria javanica type of plants have stolons that can remove the roots from each segment of the stem in contact with the ground. The roots are deep and branched so that $P$. javanica can function as an erosion deterrent and withstand a dry season that is short. Together with Centrosema pubescens, Pueraria javanica, and Calopogonium mucunoides, $P$. javanica was able to reduce cumulative sediment by $89.57 \%$ at the disposal site and $96.62 \%$ at a low wall in a pit when the jute net method was used. This means that this method has proven effective in reducing erosion for post-mining areas (Bargawa et al. 2019). Other studies have shown that $P$. javanica is a type of vegetation that has better growth. $P$. javanica is resistant to acid soils, soils deficient in lime and phosphorus. The ability of vegetation to strengthen soil binding capacity is an important factor in the selection of plant species for ecosystem restoration. Other important vegetation variables are related to plant growth such as vegetation community, vegetation cover, and quality of soil amendments produced in artificial plants such as tensile strength, permeability coefficient, soil texture, and organic matter. The five 
highest-ranking variables that satisfy environmentalists and civil engineers are rain intensity, seepage water, slope angle, drainage conditions, and soil layer (Kil et al. 2016). Hydroseeding application has been shown to reduce runoff and large sediment yields were observed in the treated plots. This result can be attributed to the combined effect of: (a) application of straw and mulch to the soil surface which provides protection against the impact of raindrops (b) general improvements to soil structure caused by organic amendments (Montoro et al. 2000).

The outcome of this restoration practice depends to a greater extent on the seed mixtures that are used and these are usually made of commercial grasses and legumes. Commercial mixtures are usually successful in producing a plant cover over the first few years, but often fail in the medium-long term, since a self-sustaining vegetation cover is only guaranteed through the use of ecologically adapted alpine species (Krautzer et al. 2013). The use of hydroseeding techniques with latex and PAM soil stabilizer types in the mixture has no significant effect on growth. Therefore, both types of soil stabilizers can be used in the hydroseeding mixture. In dryland moss restoration process, guar tended to decrease growth, psyllium tended to increase growth, and PAM's effects were generally neutral to positive when compared to water (Blankenship et al. 2020). The use of mulch and compost also greatly influenced the growth of pioneer plants. Hydroseeding formula $C$. brevifolius, $C$. eragrostis, C. odoratus, $C$. strigosus, and Kyllingia monocephala with a mixture of mulch from buffalo fecal compost grown on post-mining soil media had the highest apparent density at the age of 20 DAP, namely 23 individuals per pot compared to other media (Yulianingsih and Arisoesilaningsih 2015). Another study stated that the mixture of seed, organic tackifier, starter fertilizer, superabsorbent, bio-humus, cellulose fiber mulch, natural yarn, and water significantly supported the parameters of seed germination and grass biomass production. This hydroseeding mixture significantly reduces the amount of irrigation water through the production of an absorbent layer (Parsakhoo et al. 2018). Hydro seeded plots attained the highest plant counts and exhibited the same monthly percent visual cover as hydro mulch capped seedlings (Baldos et al. 2017). In accordance with other studies, organic manure content in a growing medium had a significant effect on seed germination and seedling growth characteristics (Anshari et al. 2018b; Samir et al. 2016). The use of the right composition is necessary considering that the application of hydroseeding is very wide, even for wetland ecosystems (Tilley and John 2013). The success of hydroseeding applications can support the formation of new ecosystems that attract Arthropods, such as grasshoppers and ground-beetles (Kessler et al. 2012; Negro et al. 2013). This is necessary to ensure for ecosystem cycle.

In conclusion, this study showed that the slope level affected the germination rate of $C$. brevifolius seeds. The hydroseeding formula had a significant effect on all variables, except for the height of $C$. brevifolius seedlings. There was a significant interaction effect between the slope level and hydroseeding treatment on the germination rate of both species but the effect of this interaction was not significant on plant height and leaf number. The best germination rates are found in boxes with a slope of $100 \%$. This situation is consistent for both species. This indicates that both species have the potential to be used as pioneer plants in post-landslide reclamation with a slope of $100 \%$. Unlike $P$. javanica, green kylingga does not germinate in the control box at an inclination of $140 \%$. This situation means that the effect of the hydroseeding formula on grass growth is substantial. Kylingga's germination rate tends to be lower (less than 20\%) compared to P. javanica.

\section{ACKNOWLEDGEMENTS}

We would like to thank the Ministry of Education and Culture of Indonesia for funding through junior lecturer scheme research in 2020.

\section{REFERENCES}

Albaladejo J, Alvarez-Rogel J, Querejeta J, Diaz-Pereira E, Castillo V. 2000. Three hydro-seeding revegetation techniques for soil erosion control on anthropic steep slopes. Land Degrad Dev 11 (4): 315-325.

Anshari MF, Boedianto E, Fernandes AAR, Arisoesilaningsih E. 2018a. Hydroseeding application using pioneer local plant seeds for coal postmining soil in Tanah Laut Regency, South Kalimantan. J Degraded Mining Land Manag 5 (4): 1335-1345. DOI: 10.15243/jdmlm.2018.054.1335

Anshari MF, Fernandes AAR, Arisoesilaningsih E. 2018b. Comparing seeds germination of some local plant species on two hydroseeding mulches for post-mining revegetation. J Degraded Mining Land Manag 5 (2): 1103-1110. DOI: 10.15243/jdmlm.2018.052.1103.

Baldos OC, DeFrank J, Lukas SB. 2017. Evaluation of 3 hydromulch planting techniques for establishing Fimbristylis cymosa (mau'u 'aki'aki), a native Hawaiian coastal sedge with roadside revegetation and landscape ground cover potential. Native Plant J 18: 20-31.

Bargawa WS, Putra A, Nurcholis M. 2019, Analysis of erosion using hydroseeding on post-coal mining in Melak site. Intl J Geomate 17: 371- 377

Blankenship WD, Condon LA, Pyke DA. 2020. Hydroseeding tackifiers and dryland moss restoration potential. Restor Ecol 28: S127-S138. DOI: $10.1111 /$ rec.12997.

Chen YC, Wu CF, Lin Sh. 2014. Mechanisms of forest restoration in landslide treatment areas. Sustainability 6 (10): 6766-6780. DOI: $10.3390 /$ su6106766.

Clemente AS, Moedas AR, Oliveira G, Martins-Loução MA, Correia O. 2016. Effect of hydroseeding components on the germination of Mediterranean native plant species. J Arid Environ 125: 68-72. DOI: 10.1016/j.jaridenv.2015.09.017

García-Palacios P, Soliveres S, Maestre FT, Escudero A, Castillo-Monroy AP, Valladares F. 2010. Dominant plant species modulate responses to hydroseeding, irrigation and fertilization during the restoration of semiarid motorway slopes. Ecol Eng 36: 1290-1298. DOI: 10.1016/j.ecoleng.2010.06.005.

Hadmoko DS, Lavigne F, Sartohadi J, Hadi P, Winaryo. 2010. Landslide hazard and risk assessment and their application in risk management and landuse planning in eastern flank of Menoreh Mountains, Yogyakarta Province, Indonesia. Nat Hazards 54: 623-642. DOI: 10.1007/s11069-009-9490-0

Jaffre T. 1992. Floristic and ecological diversity of the vegetation on ultramafic rocks in New Caledonia. The vegetation of ultramafic (serpentine) soils: Proceedings of The First International Conference on Serpentine Ecology.

Kementerian Pekerjaan Umum dan Perumahan Rakyat. 2018. Penerapan teknologi hydroseeding untuk pengendalian erosi permukaan lereng jalan. Pedoman Bahan Konstruksi Bangunan dan Rekayasa Sipil. [Indonesian] 
Kessler T, Cierjacks A, Ernst R, Dziock F. 2012. Direct and indirect effects of ski run management on alpine Orthoptera. Biodivers Conserv 21: 281-296.

Kil SH, Lee DK, Kim JH, Li MH, Newman G. 2016. Utilizing the analytic hierarchy process to establish weighted values for evaluating the stability of slope revegetation based on hydroseeding applications in South Korea. Sustainability 8: 58. DOI: 10.3390/su8010058

Krautzer B, Graiss W, Klug B. 2013. Ecological restoration of ski runs. In: Rixen C, Rolando A (eds) The Impacts of Skiing and Related Winter Recreational Activities on Mountain Environments. Bentham Ebooks, UK

Montoro JA, Rogel JA, Querejeta J, Díaz E. and Castillo V. 2000. Three hydro-seeding revegetation techniques for soil erosion control on anthropic steep slopes. Land Degraded Dev 11 (4): 315-325. DOI 10.1002/1099-145X(200007/08)11:4<315::AID-LDR394>3.0.CO;2-4

Negro M, Rolando A, Barni E, Bocola D, Filippa G, Freppaz M, Isaia M, Siniscalco C, Palestrini C. 2013. Differential responses of grounddwelling arthropods to ski-piste restoration by hydroseeding. Biodiv Conserv 22: 2607-2634. DOI: 10.1007/s10531-013-0544-y

Oliveira G, Clemente AS, Nunes A, Correia O. 2013. Limitations to recruitment of native species in hydroseeding mixtures. Ecol Eng 57: 18-26. DOI: 10.1016/j.ecoleng.2013.04.015.

Parsakhoo A, Jajouzadeh M, Motlagh RA. 2018. Effect of hydroseeding on grass yield and water use efficiency on forest road artificial soil slopes. J For Sci 64: 157-163.
Samir M, Sai R, Prasad B. 2016. Effect of organic manures on seed germination and seedling growth of Khirni. Indian For 42 (7): 666669.

Stanchi S, Freppaz M, Agnelli A, Reinsch T, Zanini E. 2012. Properties, best management practices and conservation of terraced soils in Southern Europe (from Mediterranean areas to the Alps): A review. Quat Int 265: 90-100. DOI: 10.1016/j.quaint.2011.09.015.

Stokes A, Atger C, Bengough AG. Fourcaud T, Roy CS. 2009. Desirable plant root traits for protecting natural and engineered slopes against landslides. Plant Soil 324: 1-30. DOI: 10.1007/s11104-009-0159-y

Thomas C, Sexstone A, Skousen J. 2015. Soil biochemical properties in brown and gray mine soils with and without hydroseeding. Soil 1: 621-629. DOI: 10.5194/soil-1-621-2015

Tilley DJ, John LS. 2013. Hydroseeding improves field establishment of Nebraska sedge regardless of seed treatment. Native Plant J 14: 8994. DOI: 10.3368/npj.14.2.89.

Weerasinghe UR, Akiko S, Palitha J, Seiki T. 2008. The role of the soil seed bank in vegetation recovery on an oceanic island severely damaged by introduced goats. Appl Veg Sci 11 (3): 355-364.

Yulianingsih D, Arisoesilaningsih E. 2015. Aplikasi beberapa mulsa hydroseeding untuk perkecambahan biji teki pioner di tanah pasca pertambangan batubara dari Kalimantan Selatan. Jurnal Biotropika 3 (1): 27-31. [Indonesian] 